\title{
Amino Acid Composition of Cowpea (Vigna ungiculata L. Walp) Flour and Its Protein Isolates
}

\author{
Sirelkhatim Balla Elhardallou1, Ikhlas Ibrahim Khalid², Adil Abdalla Gobouri', \\ Shams H. Abdel-Hafez ${ }^{1}$ \\ ${ }^{1}$ Department of Chemistry, Faculty of Science, Taif University, Taif, KSA \\ ${ }^{2}$ Faculty of Science, Shagra University, Shagra, KSA \\ Email: drhardallou@yahoo.com
}

Received 2 January 2014; accepted 14 June 2015; published 17 June 2015

Copyright @ 2015 by authors and Scientific Research Publishing Inc.

This work is licensed under the Creative Commons Attribution International License (CC BY). http://creativecommons.org/licenses/by/4.0/

(c) (i) Open Access

\begin{abstract}
The study of the nutritive value of Cowpea (Vigna ungiculata L.) legume seed is needed, as this legume is a food source in many developing countries. Whole Cowpea Flour (WCF), Dehulled Defatted Cowpea Flour (DDCF), and Cowpea Protein Isolates (CPI) prepared using Isoelectric method (CPII) and using Micellization method (CPIM) are studied. In proximate analysis, the protein content of WCF, DDCF, CPIA and CPIB was found to be 22.3, 26.7, 750 and $76.0 \mathrm{~g} / 100 \mathrm{~g}$, respectively. Net protein value (NPV) was 17.62 for DDCF. Chemical score was $0.66 \%$ for DDCF and $112 \%, 104 \%$ for CPII and CPIM, respectively. The first limiting amino acid was cystine for DDCF and threonine for CPII and CPIM. Methionine was found to be the most concentrated essential amino acid in both CPII and CPIM; values were 27.22 and $30.60 \mathrm{~g} / 16 \mathrm{~g}$ N, respectively, while lysine was the most abundant essential amino acid in DDCF ( $4.28 \mathrm{~g} / 16 \mathrm{~g} \mathrm{~N})$. Essential amino acids of CPIi and CPIM were 22.99 and $15.78 \mathrm{~g} / 16 \mathrm{~g} \mathrm{~N}$ respectively, higher than $\mathrm{FAO} / \mathrm{WHO}$ reference.
\end{abstract}

\section{Keywords}

Legumes, Cowpea Seeds, Protein Isolates, Composition, Amino Acids, Nutritive Value

\section{Introduction}

Food crops have occupied an important place in human nutrition as they remain the major sources of calories and proteins for a large proportion of the world population. Legumes and cereals, the main plant sources of proteins in human diet, are in addition rich in dietary fibre and carbohydrates [1]. Minor compounds of legumes are 
lipids, polyphenols, and bioactive peptides [2]. Legumes will therefore continue to play an important part in diets in the foreseeable future. Legumes provide a good source of protein $(18 \%-35 \%)$, and supplement cereals not only for protein but also for minerals and vitamins of B complex. This is particularly important when refined cereals such as white wheat flour are used in a poor diet with few supplementary foods.

Legumes have been promoted as a source of protein in countries with high rates of protein-energy malnutrition. Cowpeas are abundant in these countries and contain proteins, carbohydrates, water soluble vitamins and minerals [3]. The cowpea (Vigna ungiculata L. Walp) is a grain legume believed to have originated in Africa and Asia [4], and is widely cultivated in the tropics [5]. As a legume, cowpeas are rich and low-cost sources of proteins and nutrients [6] and they form part of staple diet in most African and Asian countries. Cowpeas are consumed as boiled vegetables using fresh or rehydrated seeds or processed into flour to make other food products. Major limiting factors to the utilization protein quality include poor digestibility, deficiency of sulphur amino acids and presence of anti-nutritional factors such as trypsin inhibitors, oligosaccharides and phenolic compounds [5] [7] [8]. Thus cowpea must be adequately processed, especially when it is used as a main component of the diet of young children. Proteins are major components of legume seeds. Their nutritional and functional properties dramatically affect the overall quality of the seed and its technological performance [9]. The crude protein of cowpea seeds ranged from $18 \%$ to $35 \%$ based on variety and the protein of cowpeas was found deficient in methionine and tryptophan [10]. The digestibility of the diet containing cowpea protein isolate was $87 \%$ and showed positive nitrogen balance $(\mathrm{NP}=0.5)$ and a net protein retention (NPR) of 0.7 [11]. This study aims to investigate the nutritive value of cowpea seeds, as one of the legumes widely consumed in developing countries. Further studies are needed for a multi-parameter approach in quality evaluation [12] and on the effect of processing on finished products [13].

\section{Materials and Methods}

Samples: Dehulled cowpea (Vigna unguiculata L. Walp) of white coloured seed (Figure 1) was brought from the local market at Wad Medani city, Gezira state, Sudan. The seeds were stored in polyethylene bags at room temperature.
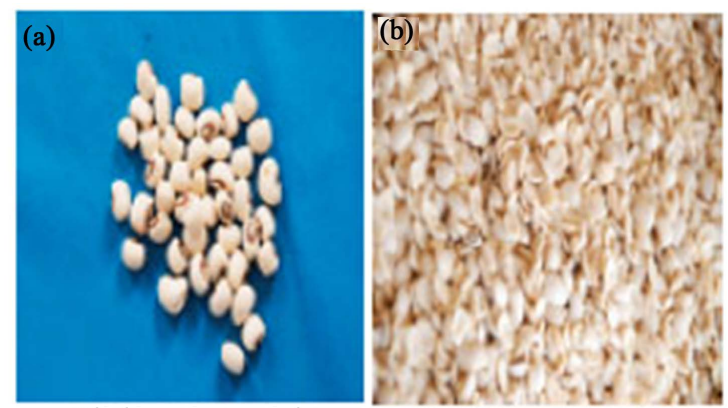

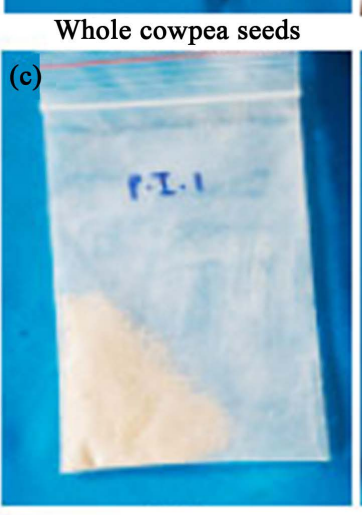

CP1I
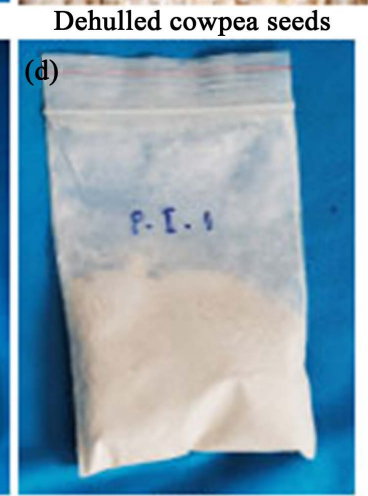

$\mathrm{CP} 1 \mathrm{M}$

Figure 1. (a) Whole cowpea seeds; (b) Dehulled cowpea seeds; (c) CPII: cowpea protein isolate prepared by isoelectric precipitation; (d) CPIM: cowpea protein isolate prepared by micellization precipitation. 


\section{S. B. Elhardallou et al.}

Seeds were ground to a flour passing 35 mesh, defatted by soaking in petroleum ether $\left(\mathrm{BP} .40^{\circ} \mathrm{C}-60^{\circ} \mathrm{C}\right.$ ) for $48 \mathrm{~h}$ with several changes of the solvent. The solvent decanted and defatted flour was then air dried over night at $\left(27^{\circ} \mathrm{C}\right)$ and kept in clean bottles.

Preparation of cowpea protein isolate (CPI) by isoelectric precipitation (CPII): CPII was prepared from cowpea seed flour as shown in Figure 2 following the method described by Thompson [with slight modifications [14] [15].

The insoluble matrices were separated by refrigerated centrifugation at $4 \times 103 \mathrm{~g}$ for $20 \mathrm{~min}$ and discarded. Extraction and centrifugation procedures were repeated. The supernatant was adjusted to $\mathrm{pH} 4.0$ with $1.0 \mathrm{~N} \mathrm{HCl}$ and stirred at room temperature for $20 \mathrm{~min}$; followed by refrigerated centrifugation ( $4000 \mathrm{~g}, 20 \mathrm{~min}$ ). The precipitate was washed by distilled water several times to free it from salt; neutralized to $\mathrm{pH} 7.0$ using $1.0 \mathrm{~N} \mathrm{NaOH}$ and left over night in refrigerator $\left(4.0^{\circ} \mathrm{C}\right)$. The isolate was freeze dried, ground into powder using a ceramic mortar and pestle and stored in a desiccators.

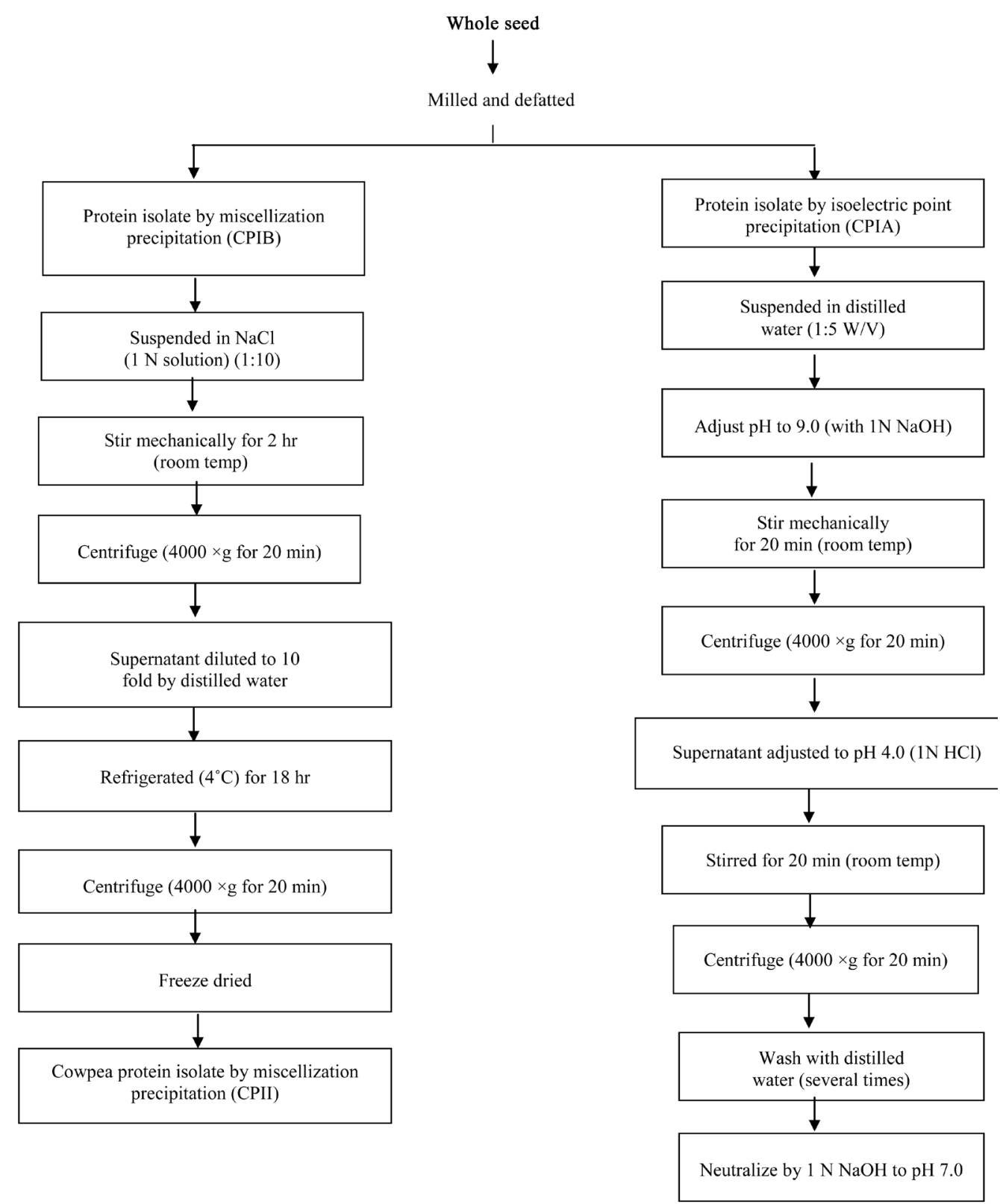

Figure 2. Preparation of cowpea protein isolates by isoelectric (CPII) and micellization precipitate (CPIM). 
Preparation of cowpea protein isolate (CPI) by micellization precipitation (CPIM): CPIM was prepared using micella method [16] as presented in Figure 2. The defatted seed flour was suspended in $\mathrm{NaCl} 1.0 \mathrm{~N}$ solution in a 1:10 (w/v) ratio, then stirring for $2 \mathrm{~h}$ at room temperature. The suspension was centrifuged at 3000x $\mathrm{g}$ for $30 \mathrm{~min}$ and then the residue was extracted again as described above. The combined supernatant was diluted ten folds by distilled water and left to stand at $\left(4^{\circ} \mathrm{C}\right)$, in refrigerator, for $18 \mathrm{~h}$.

Chemical composition: Cowpea seed flour and protein isolate composition were determined following methodology for total nitrogen (Kjeldahl), fat (Soxhlet), carbohydrates, moisture and ash (gravimetrically) and crude fibre by a chemical-gravimetric method [17] and the means reported on dry weight basis.

Amino acid analysis: Amino acids analysis was performed on (DDCF) and protein isolates using amino acid analyze chromatography method [18] and quantified after reaction with ninhydrin. Each sample was hydrolyzed with $6 \mathrm{~N} \mathrm{HCl}$ at $110^{\circ} \mathrm{C}$ for $24 \mathrm{~h}$. The amino acid composition was calculated considering the highest value for each amino acid. Sulfur-containing amino acids were determined after performing acid oxidation.

Biological values of cowpea seed flours and isolates were determined on the basis of its amino acid profile. Chemical score was calculated [19]. The content of each essential amino acid in test protein was expressed as a percentage of the content of the same amino acid in a standard protein. Amino acid was calculated using the FAO/WHO [20] reference pattern. The amino acid showing the lowest percentage was called the "limiting amino acid" representing the chemical score. Essential amino acid index (EAAI) was calculated according to [21] using the amino acid composition of the whole egg protein [22].

Protein efficiency ratio (PER) was estimated according to the following regression equation [23].

Predicted protein efficiency ratio (P-PER)

$$
\mathrm{P}-\mathrm{PER}=-0.468+0.454 \text { (Leucine) }-0.105 \text { (Tyrosine) }
$$

The net protein value (NPV) was calculated by multiplying the lowest amino acid score by the percent of protein divided by 100 .

$$
\mathrm{NPV}=(\text { The lowest amino acid score } \times \% \text { protein }) / 100
$$

\section{Results and Discussion}

Chemical composition: Chemical composition of dehulled defatted cowpea flour (DDCF) and protein isolates (CPII and CPIM) (Table 1). The whole (WCF) and dehulled defatted (DDCF) cowpea seed flour contained $22.30 \%-26.73 \%$ protein, $2.10 \%-2.30 \%$ fat, $4.10 \%-1.02 \%$ fibre, $3.77 \%-3.87 \%$ ash and $60 \%-59 \%$ carbohydrates, respectively (on dry weight basis) as major components. The CPIM showed significantly $(\mathrm{p}<0.05)$ higher protein than the CPII but the fat, ash and crude fibre contents of both isolates were similar. Protein isolate by micellization techniques, the protein association was favored when ionic strength $(\mu)$ of the extract sample was reduced [24] [25]. This may be the main reason this isolate had higher protein content. Some salts bind to protein when present at relatively high concentrations, the increase in net charge due to ion binding results in increased repulsive forces and destabilization of the protein [26].

Table 1. Proximate composition of whole cowpea flour (WCF), dehulled defatted cowpea flour (DDCF) and protein isolates

\begin{tabular}{|c|c|c|c|c|c|}
\hline Chemical constituents & WCF & DDCF & CPIA & CPIB & LSD \\
\hline Crude protein $(\mathrm{N} \times 6.25)$ & $22.30 \mathrm{~d} \pm 0.20$ & $26.73 c \pm 0.06$ & $75.0 \mathrm{~b} \pm 0.06$ & $76.0 \mathrm{a} \pm 0.12$ & 0.26 \\
\hline Crude fat & $2.10 \mathrm{a} \pm 0.10$ & $2.30 \mathrm{a} \pm 0.10$ & Traces & Traces & 0.43 \\
\hline Crude fibre & $4.10 \mathrm{a} \pm 0.20$ & $1.02 b \pm 0.08$ & Traces & Traces & 0.35 \\
\hline Total ash & $3.77 a \pm 0.06$ & $3.87 \mathrm{a} \pm 0.06$ & $2.63 b \pm 0.15$ & $2.3 b \pm 0.20$ & 0.55 \\
\hline Carbohydrate & $60.07 a \pm 0.06$ & $59.78 a \pm 0.28$ & $13.0 \mathrm{~b} \pm 0.17$ & $13.1 b \pm 0.0$ & 0.43 \\
\hline
\end{tabular}
(CPII) and (CPIM) \% dry basis.

Means in the same raw with different letters are significantly different $(\mathrm{p}<0.05)$. Means \pm Standard deviation of triplicate analysis. LSD: Least significant differences; CPII: Cowpea protein isolate prepared by isoelectric point precipitation; CPIM: Cowpea protein isolate prepared by micellization precipitation. 
Amino acid composition: The protein quality or the nutrient value of food depends on its amino acid content and on the physiological utilization of specific amino acid after digestion, absorption and utilization. The two prepared protein isolates are rich in isoleucine, leucine, lysine and total aromatic amino acids (tyrosine and phenyl alanine) (Table 2). Similar observations were reported [27]. Methods based on in vitro (chemical and amino acids bioassay) for assessment of protein quality is important.

Amino acid composition of the DDCF and protein isolates CPII and CPIM are reported as g/16 g N comparing to the [20] (Table 2). The protein isolates are rich in leucine the values were 8.8 and $8.9 \mathrm{~g} / 16 \mathrm{~g} \mathrm{~N}$ for CPII and CPIM respectively. This result was similarly reported [15] 8.0 and $8.4 \mathrm{~g} / 16 \mathrm{~g} \mathrm{~N}$ for pea and faba bean proteins isolates. Methionine was the most essential amino acids in both protein isolates (CPII and CPIM). The protein isolates showed, in general higher total essential and nonessential amino acid levels than their own original seeds (Table 3). Cystine is most limiting sulphur containing amino acid in cowpea flour (Table 4). This is a general nutrient problem with most of the legume seeds. In fact, both isolates showed higher levels of total sulphur and aromatic amino acids compared to original seeds. The essential/non essential ratios showed slight increase in the protein isolates profile compared to the ratio in their respective seeds. On the basis of chemical scores both isolates have higher chemical scores than the legume seeds (Table 4). Net protein value of protein isolate CPII was higher than isolate CPIM.

The low (leucine:isoleucine) ratio in both cowpea protein isolates was desirable because it leads to amino acid balance in cereals that are already high in leucine and low in tryptophan and isoleucine.

Both isolates (CPII and CPIM) had higher content from non essential amino acids than cowpea flour Figure 3. However, the hydrophobic amino acids (leucine, isoleucine and valine) were more abundant in CPIM (23.66) than in CPII (22.33).

Table 2. Amino acid composition of dehulled defatted cowpea flour (DDCF) and cowpea protein isolates (CPII and CPIM).

\begin{tabular}{|c|c|c|c|c|}
\hline Amino acid & DDCF & CPII & CPIM & FAO/WHO (1973) (g/16 g nitrogen) \\
\hline Isolucine & 0.98 & 7.92 & 8.20 & 4.0 \\
\hline Leucine & 1.58 & 8.81 & 8.85 & 7.0 \\
\hline Lysine & 4.28 & 22.99 & 15.78 & 5.50 \\
\hline Cystine & 0.032 & 0.06 & - & 3.5 \\
\hline Methionine & - & 27.22 & 30.60 & 3.5 \\
\hline Tyrosine & 3.33 & 16.31 & 19.83 & 6.0 \\
\hline Phenylalanine & 2.0 & 12.37 & 11.96 & 6.0 \\
\hline Threonine & 0.44 & 7.18 & 4.18 & 4.0 \\
\hline Tryptophan & ND & ND & ND & 1.0 \\
\hline Valine & 0.72 & ND & 6.61 & 5.0 \\
\hline Histidine & 0.77 & 7.88 & 9.07 & - \\
\hline Argnine & 2.66 & 17.09 & 19.26 & - \\
\hline Aspartic & ND & ND & ND & - \\
\hline Glutamic acid & 3.32 & 21.49 & 39.69 & - \\
\hline Serine & 0.89 & 8.09 & 11.19 & - \\
\hline Proline & 7.71 & 23.14 & 24.33 & - \\
\hline Glysine & 0.68 & 3.32 & 3.97 & - \\
\hline Alanine & 0.89 & 2.74 & 3.0 & - \\
\hline
\end{tabular}

CPII = Cowpea protein isolate by isoelectric point precipitation; CPIM = Cowpea Protein Isolate by micellization precipitation. 


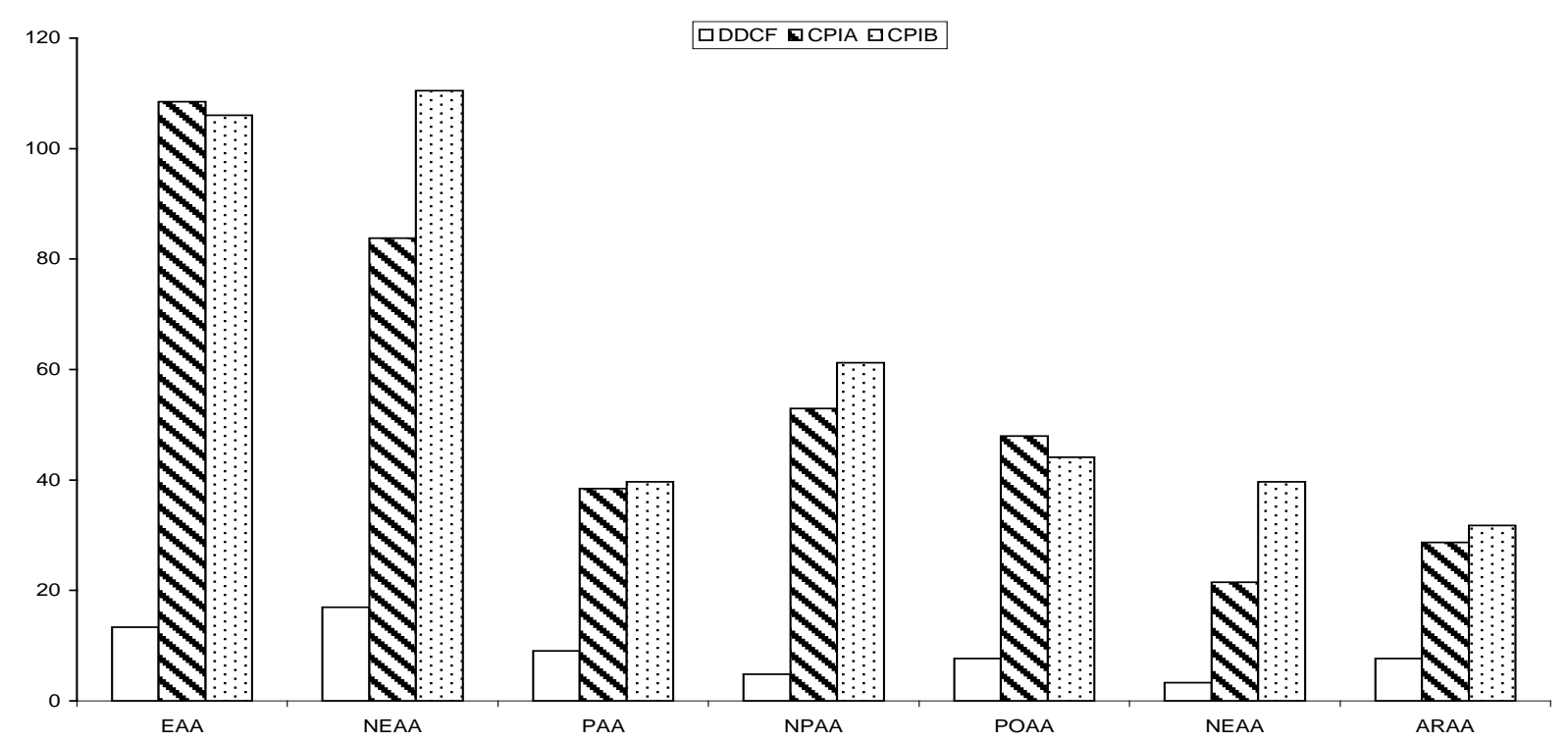

Figure 3. Evaluation of protein quality based on amino acid composition in dehulled defatted cowpea flour (DDCF) and protein isolates (CPII and CPIM). EAA: Essential amino acids; POAA: Positively amino acids; NPAA: Non polar amino acids; NEAA: Non essential amino acids; NEAA: Negatively charge amino acids; PAA: Polar amino acids; ARAA: Aromatic amino acid.

Table 3. Classification of amino acids (g/16 g) of dehulled defatted cowpea flour (DDCF) and protein isolates (CPII) and (CPIM).

\begin{tabular}{cccc}
\hline Amino acid description & DDCF & CPII & CPIM \\
Total amino acids (TAA) & 30.28 & 192.21 & 216.52 \\
Total essential amino acids (TAA) with histidine & 14.13 & 156.34 & 115.08 \\
Total essential amino acids (TAA) without histidine & 13.36 & 108.46 & 106.01 \\
Total non essential amino acids (TNAA) & 16.92 & 83.75 & 110.51 \\
Essential aromatic amino acid (EArAA) & 5.33 & 28.68 & 31.79 \\
Total acid amino acid (TAAA) & 3.32 & 21.49 & 39.69 \\
Total basic amino acid (TBAA) & 8.79 & 23.98 & 22.05 \\
Total sulphur amino acid (TSAA) & 0.032 & 27.28 & 30.60 \\
\hline
\end{tabular}

CPII = Cowpea protein isolate by isoelectric point precipitation; CPIM = Cowpea protein isolate by micellization precipitation.

Table 4. Estimation of nutritional quality of dehulled defatted cowpea flour (DDCF) and protein isolates (CPII and CPIM) based on amino acids composition.

\begin{tabular}{|c|c|c|c|c|c|c|c|}
\hline \multirow{2}{*}{ Materials } & \multirow{2}{*}{$\begin{array}{l}\text { Protein } \\
(\%)\end{array}$} & \multicolumn{3}{|c|}{ Limiting amino acids } & \multirow{2}{*}{ MEAA } & \multirow{2}{*}{$\begin{array}{l}\text { Chemical } \\
\text { score \% }\end{array}$} & \multirow{2}{*}{ NPV } \\
\hline & & First & Second & Third & & & \\
\hline Dehulled defated cowpea flour (DDCF) & 26.7 & Cystine & Threonine & Valine & -100 & 0.66 & 17.62 \\
\hline Cowpea protein idolate-A (CPII) & 75.0 & Valine & Leucine & Threonine & 1.87 & 112.0 & 8400.0 \\
\hline Cowpea protein isolate-B (CPIM) & 76.0 & Threonine & Leucine & Vlaine & 1.47 & 104.5 & 7942.0 \\
\hline
\end{tabular}

DDCF = Dehulled defatted cowpea flour; CPII = Cowpea protein isolate by isoelectric point precipitation; CPIM = Cowpea protein isolate by micellization precipitation; MEAA = Michel essential amino acids index; NPV = Net protein value.

The basic amino acids (BAA) were found greater than total acidic amino acids (AAA) (aspartic amino acid not detected in all samples), indicating that the protein is probably basic in nature. 


\section{Conclusions}

Whole cowpea flour (WCF), de-hulled defatted cowpea flour (DDCF) and protein isolates obtained by isoelectric (CPII) and micellization (CPIM) precipitation have shown some changes in the proximate composition. Crude fibre decreased from $4.1 \%$ in WCF to $1.02 \%$ in DDCF, while crude protein increased from $22.3 \%$ in WCF to $26.75 \%$ in DDCF. Protein isolates (CPII and CPIM) showed $75 \%$ and $76 \%$ protein content and a decrease in carbohydrate content from $59.78 \%$ to $13 \%$.

The first limiting amino acid was cystine (0.032 g/16 g nitrogen) for DDCF and threonine (5.60 and $4.18 \mathrm{~g} / 16$ g nitrogen) for CPIA and CPIB, respectively. Essential amino acids of CPII and CPIM were found in an acceptable level in comparison with reference protein. Both protein isolates were higher than FAO/WHO in lysine content. The values were 22.99 and $15.78 \mathrm{~g} / 16 \mathrm{~g} \mathrm{~N}$ in protein isolates CPII and CPIM respectively. Methionine was found to be the most concentrated essential amino acids in both protein isolates (CPII and CPIM), with values ranging from 27.22 to $30.60 \mathrm{~g} / 16 \mathrm{~g} \mathrm{~N}$ respectively, while lysine was the most abundant essential amino acid in DDCF (4.28 g/16 g N). Net protein values (NPV) were 17.62 for DDCF and (8400 - 7942) for CPII and CPIM respectively. Chemical scores for both isolates were above 100.

A mixed food of legumes and cereals, particularly in developing countries, can compensate deficiencies or a low level of lysine and sulphur amino acids, in cereals and grain legumes, respectively.

\section{References}

[1] Rochfort, S. and Panozzo, J. (2007) Phytochemicals for Health, the Role of Pulses. Journal of Agricultural and Food Chemistry, 55, 7981-7994. http://dx.doi.org/10.1021/jf071704w

[2] Pastor-Cavada, E., Juan, R., Pastor, J.E., Alaiz, M. and Vioque, J. (2009) Analytical Nutritional Characteristics of Seed Proteins in Six Wild Lupinus Species from Southern Spain. Food Chemistry, 117, 466-469. http://dx.doi.org/10.1016/j.foodchem.2009.04.039

[3] Frieddman, M. (1996) Nutritional Value of Proteins from Different Food Sources. A Review. Journal of Agriculture Food Chemistry, 44, 6-29. http://dx.doi.org/10.1021/jf9400167

[4] Taiwo, K.A. (1998) The Potential of Cowpea as Human Food in Nigeria. Technovation, 18, 469-481. http://dx.doi.org/10.1016/S0166-4972(98)00015-7

[5] Chavan, J.K., Kadam, S.S. and Salunkhe, D.K. (1989) Cowpea in: Hand Book of World Food Legume: Nutritional Chemistry, Processing Technology and Utilization, Volume 2. Salunkhe and Kadam, Eds., CRC Press, Florida.

[6] Egouniety, M. and Aworh, O.C. (2003) Effect of Soaking, Dehulling, Cooking and Fermentation on the Oligosaccharides, Trypsin Inhibitors, Phytic Acid and Tannins of Soybean (Glysin max Merr.), Cowpea (Vigna ungiculata Walp) and Ground Bean (Mccrotyloma geocarpa Harms). Journal of Engineering, 56, 249-254.

[7] Evans, M. and Boulter, D. (1980) Crude Protein and Sulphur Amino Acids Contents of Some Commercial Varieties of Peas and Beans. Journal of Science Food Agriculture, 31, 238-242. http://dx.doi.org/10.1002/jsfa.2740310304

[8] Gwiazda, S., Schwenke, K.D. and Rutkowski, A. (1980) Isolation and Partial Characterization of Proteins from Pea (Pisum sativum L.). Nahrung, 24, 939-950. http://dx.doi.org/10.1002/food.19800241003

[9] Duranti, M. and Gius, C. (1997) Legume Seeds: Protein Content and Nutritional Value. Field Crops Research, 53, 3145. http://dx.doi.org/10.1016/S0378-4290(97)00021-X

[10] Kachare, D.P., Chavan, J.K. and Kadam, S.S. (1987) Nutritional Quality of Some Improved Cultivars of Cowpea. Plants Food for Human Nutrition, 38, 155-162.

[11] Rangel, A., Saraiva, K., Schwengber, P., Narciso, M.S., Domont, G.B., Ferreira, S.T. and Pedrosa, C. (2003) Biological Evaluations of a Protein Isolate from Cowpea (Vigna ungiculata) Seeds. Food Chemistry, 87, 491-499. http://dx.doi.org/10.1016/j.foodchem.2003.12.023

[12] Kahl, J., Baars, T., Bügel, S., Busscher, N., Huber, M., Kusche, D., Rembialkowska, E., Schmid, O., Seidel, K., Taupier-Letage, B., Velimirov, A. and Zalecka, A. (2012) Organic Food Quality: A Framework for Concept, Definition and Evaluation from the European Perspective. Journal of the Science of Food and Agriculture, 92, 2760-2765. http://dx.doi.org/10.1002/jsfa.5640

[13] Seidel, K., Kahl, J., Paoletti, F., Birlouez, I., Busscher, N., Kretzschmar, U., Särkkä-Tirkkonen, M., Seljåsen, R., Sinesio, F. and Torp, T. (2015) Quality Assessment of Baby Food Made of Different Pre-Processed Organic Raw Materials under Industrial Processing Conditions. Journal Food Science and Technology, 52, 803-812. http://dx.doi.org/10.1007/s13197-013-1109-5

[14] McCurdy, S. and Kniptel, J. (1990) Investigation of Faba Bean Protein Recovery and Application to Pilot Scale Processing. Journal Food Science, 55, 1093-1094. http://dx.doi.org/10.1111/j.1365-2621.1990.tb01606.x 
[15] Fernandez-Quintela, A., Maccrulla, M.T., Del-Barrio, A.S. and Martinez, J.A. (1997) Composition and Functional Properties of Protein Isolates Obtained from Commercial Legumes Grown in Northern Spain. Journal Plant Foods for Human Nutrition, 51, 331-342. http://dx.doi.org/10.1023/A:1007936930354

[16] Lampart-Szczapa, E., Obuchowski, W., Czaczyk, K., Pastuszewska, B. and Buraczewska, L. (1996) Effect of Lupin Flour on the Quality and Oligosaccharides of Pasta and Crisps. Nahrung/Food, 41, 219-223.

[17] Association of Official Analytical Chemists (1998) Official Method of Analysis. 16th Edition, AOAC, Washington DC.

[18] Moore, S., Spackman, D.H. and Stein, W.H. (1958) Chromatography of Amino Acid on Sulphonated Polystyrene Resins. An Improved System. Analytical Chemistry, 30, 1185-1190. http://dx.doi.org/10.1021/ac60139a005

[19] Block, R.J. and Mitchell, H.H. (1946) The Correlation of the Amino Acid Composition of Proteins with Their Nutritive Value. Nutrition Abstracts \& Reviews, 16, 249-278.

[20] FAO/WHO (1973) Energy and Protein Requirements. Report of a Joint FAO/WHO Adhoc Expert Committee. FAO Nutritional Meeting Report Series No. 52, Technical Report Series No. 522 Food and Agriculture Organization of the United Nation, Rome.

[21] Oser, B.L. (1959) An Integrated Essential Amino Acid Index for Predicting the Biological Value of Proteins. In: Albanese, A.A., Ed., Amino Acid Nutrition, Academic Press, New York, 295-311.

[22] Hidvegi, M. and Bekes, F. (1984) Mathematical Modeling of Protein Nutritional Quality from Amino Acid Composition. In: Lazity, R. and Hidvegi, M., Eds., Proceedings of the International Association for Cereal Chemistry Symposium, Academic Kiado, Budapest, 205-286.

[23] Alsmeyer, R.H., Cunningham, A.E. and Happich, M.L. (1974) Equations Predict PER from Amino Acid Analysis. Food Technology, 28, 34-38.

[24] Paradez-Lopez, O., Ordorica-Falomir, C. and Carabez-Trejo, A. (1988) Production of Safflower Protein Isolates: Physicochemical Characterization. Lebensmittel-Wissenschaft \& Technologie, 21, 328-333.

[25] Murry, E.D., Myers, C.D. and Barker, L.D. (1981) Functional Attributes of Protein. A Non-Covalent Approach to Processing Ant Utilizing Plant Proteins. In: Stanley, D.W., Murray, E.D. and Lees, D.W., Eds., Utilization of Protein Resources, Food and Nutrition Press, Westport, 158.

[26] Arakawa, J. and Timasheff, S.N. (1982) Preferential Interactions of Proteins with Salts in Concentrated Solutions. Biochemistry, 21, 6545-6552. http://dx.doi.org/10.1021/bi00268a034

[27] Olaofe, O. and Akintayo, E.T. (2000) Production of Isoeletric Points of Legume and Oil Seed Proteins from Amino Acid Composition. Journal Technology Science, 4, 49-53. 